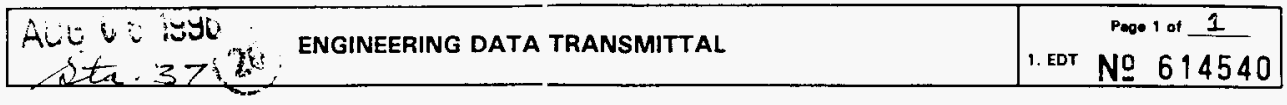

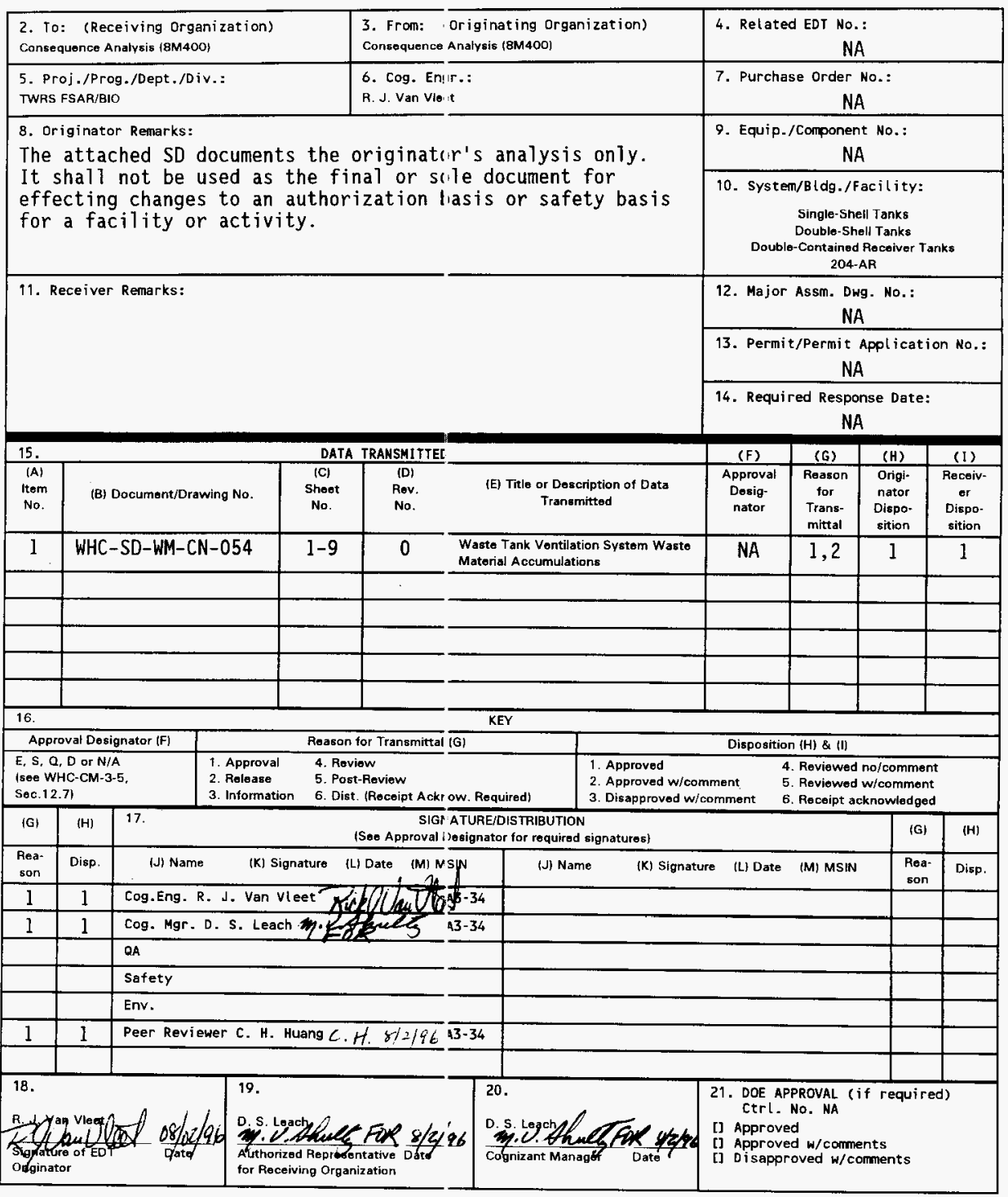

BD-7400-172-2 (04/94) GEF097 


\section{WASTE TANK VENTILATION SYSTEM WASTE MATERIAL ACCUMULATIONS}

R. J. Van Vleet

West inghouse Hanford Compan', Richland, WA 99352

U.S. Department of Energy Cintract DE-AC06-87RL10930

\begin{tabular}{|c|c|c|}
\hline $\begin{array}{l}\text { EDT/ECN: } \\
\text { Org Code: } \\
\text { B\&R Cade: }\end{array}$ & $\begin{array}{l}614540 \\
8 M 400 \\
\text { EW3120071 }\end{array}$ & $\begin{array}{l}\text { UC } 2030 \\
\text { Chitrge Code: } \\
\text { To:al Pages: }\end{array}$ \\
\hline
\end{tabular}

Key Words: HEPA filters, prefilters, ventilation system, material loading, tank färms, TWRS, double-contained receiver tanks

Abstract: This paper calculates the amount of material that accumulates in the ventilation systems of various Tank Waste Remediation System facilities and estimates the amount of material that could be released due to a rapid pressurizaticn.

TRADEMARK DISCLAIMER. Reference herein to any specific comercial product, process, or service by trade name, trademark, manufacturer, or otherwise, does not necessarily constitute or imply its endorsement, recommendation, or favoring by the United States Government or any agency thereof or its contractors or subcontractors.

Printed in the United States of America. To obtain copies of this document, contact: WHC/BCS Document Control Services, P.O. Box 197), Mailstop H6-08, Richland HA 99352, Phone (509) 372-2420; Fax (509) 376-4989.
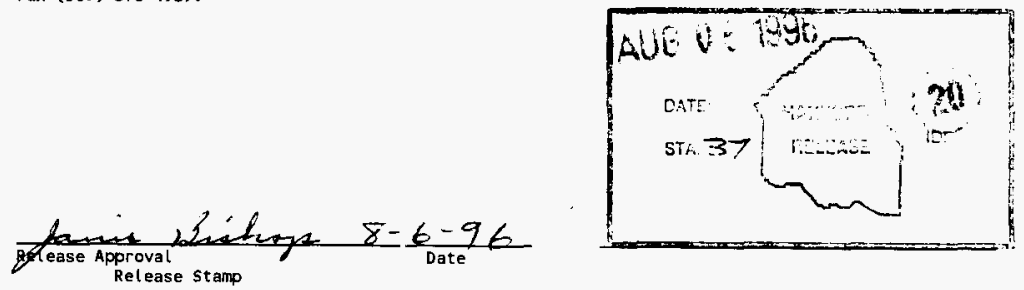

\section{Approved for Public Release}


WHC-SD-WM-CN-054, Rev. 0

This page intentionally left blank. 


\section{WASTE TANK VENTILATION SYSTEM WASTE MATERIAL ACCUMULATIONS}

This calculation note describes the method used by Savino (1996) to calculate the amount of naterial that could accumulate in the ventilation systems of varijus tank farm facilities. To perform this calculation, Savino modeled $3.7 \times 10^{10} \mathrm{~Bq}(1 \mathrm{Ci})$ of gamma emitters in different filter configurations and then calculated the contact doses that could accumulate on th? housings of these filters. Depending on the source materiat (Cowley 1996), the gamma emitters used in the calculation where different. For example, for single-shell solids, Savino used ${ }^{90} \mathrm{Sr},{ }^{90} \mathrm{Y},{ }^{137} \mathrm{Cs}$, and ${ }^{154} \mathrm{Eu}$ for the gamma emitters; while, for double-shel1 liquids Savino used predominantly ${ }^{137} \mathrm{Cs}$ (the other gamma emitters in double-shell taiks have much smaller concentrations and therefore weren't included in the calculation). The spreadsheet tables in this calculation note indicate the relative amounts of all radionuclides used for each of the cases that were analyzed.

Different filter geomutries were modeled to calculate material accumulations in the variou:i tank ventilation systems. These geometries include high-efficiency par'iculate air (HEPA) filters and prefilters. After inputing the filter grometry and the source material that might be present, a dose rate $(\mathrm{mSv} / \mathrm{hr}$.) was calculated.

HEPA filters and pref-1ters have pre-specified operating 1 imits. These operating limits were used, along with the calculated dose rate, to form a ratio of the operi.ting limit to the calculated dose limit. This ratio gives the fracticn of the assumed waste volume that could be accumulated on the filter $f(r$ the specified operating limit. The amount of material that could be $r \in$ leased to the environment from a blowout of a single bank of filters in a tank ventilation system was calculated using one of the following schemes, depending on the tank ventilation system being analyzed.

- The tank ventilation system is a standard, active ventilation system with a prefilter, and a first-stage and second-stage HEFA filter. An additional amount of release material, equal to another prefilter loading, was used to account for material that might come out of the ventilation duct work. That is, two prefilter volumes plus two HEPA filter volumes were used in the calculation.

- The tank ventilation system is passively ventilated. This system consists of one HEPA filter, sitting on a riser. There is no prefilter and there is no ventilation ducting to speak of. That is, one HEPA filter volume was used in the calculation.

- The tank ventilation system has two de-entrainers, and a first-stage and second-stage HEPA filter. To account for the accumulation of material in the de-entrainers and the material that mi ght come out of the ventilation duct work, an additional volume, equivalent to three HEPA filters, was used in the calcilation. A total of five times the material accumulation for one HEPA filter was used in the calculation. 
- The tank ventilation system consists of a prefilter, low-efficiency "ilter (treated as another prefilter), and first-stage and second-stage HEPA filters. In addition, a volume of material equal to that used for the prefilter was used in the cal:ulation to account for material from the ventilation sys zem ducting. A total of three prefilter volumes and two HEPA filter volumes were used in the calculation.

The following spreads leet pages also identify how many filter banks are in operation in a ventilation system at the same time. The total amount of material that could be released from a ventilation system can be determined by multiplying the calculated filtration system loading by the appropriate nelease fraction. For ventilation system filter blowout, the release fraction is $1 / 100$ as given in Section 5.4.4.2 of DOE-HDBK-3010-94 (DOE 1994) of the accumulated volume is released. This corresponds to the material that would be released from crushing a filter in an unc infined space. The calculated release volumes in the following speadsheet pages were used to calculate the radiological and toxicologizal doses as documented in calculation note WHC-SD-WM-CN-055 (Van Vleet 1996). An example calculation is shown here for single-she 11 tanks with active ventilation containing HEPA filter of dimension $61 \mathrm{~cm} \times 61 \mathrm{~cm} \times 3) .5 \mathrm{~cm}(24 \times 24 \times 12$ in.). Other ventilation system arrangements are treated in a similar fashion.

\section{EXAMPLE}

Savino (1996) evaluat ad the single-shell tank solid source term (Van Keuren and Savino 1996 1 . He determined that $\mathrm{Sr}^{90}, \mathrm{Y}^{90}, \mathrm{Cs}^{137}$, and $\mathrm{Eu}^{154}$ where the gamma emittens that would contribute to contact doses on the filter housing. Alpha and beta emitters will be shielded out by the HEPA filter itself or the mital housing of the filter enclosure. He apportioned $3.7 \times 10^{10} \mathrm{~Bq}(1 \mathrm{Ci}$ ) of activity on the HEPA filter in the same ratio as they appear $i$, the single-shell tank soljd source term (Cowley 1996). That is $1.8 \times 10^{10} \mathrm{~Bq}(0.484 \mathrm{C}$. $(0.484 \mathrm{C} i)$ of $\mathrm{Y}^{90}, 1.1 \times 10^{9}\left(0.0303 \mathrm{C}(\mathrm{)})\right.$ of $\mathrm{Cs}^{13}$, and $6.3 \times 10^{7} \mathrm{~Bq}$ $(0.0017 \mathrm{C} i)$ of $\mathrm{Eu}^{\prime 154}$. This loading is equivalent to $0.0112 \mathrm{~L}$ of singleshell tank solids on the fi ter. Single-shell tank solids were assumed since the vast majority of :he single shell tanks do not have supernatant layers.

This loading on the Hl:PA filter was modelled using the Microshield computer code. A contact dise rate of $0.257 \mathrm{mSv} / \mathrm{hr}$ was calculated at the filter housing. An opelating limit equal of $200 \mathrm{mR} / \mathrm{hr}$ was chosen by operations. For the purpos: of this analysis, this is equivalent to a contact dose rate of $2 \mathrm{mSv} / \mathrm{l}$, i.e., a quality factor of 1 was assumed. 
To arrive at the maxilum loading that would give the operating limit, the following equation was used.

$$
\begin{aligned}
M_{\text {HEPA }} & =\left(\frac{\text { Opera }}{\text { Calcu.ing Limit }}\right)(\text { Initial Loading) } \\
& =\left(\frac{2 \mathrm{~ms}}{0.257} \frac{\mathrm{v} / \mathrm{hr}}{\mathrm{mSV} / \mathrm{hr}}\right)(0.0112 \mathrm{~L}) \\
& =0.0872 \mathrm{~L}
\end{aligned}
$$

A similar calculation was done for the pre-filters.

$$
\begin{aligned}
M_{\text {prefilter }} & =\left(\frac{2 \mathrm{mSv} / \mathrm{hI}}{0.34 \mathrm{mSv} / \mathrm{hI}}\right)(0.0112 \mathrm{~L}) \\
& =0.0659 \mathrm{~L}
\end{aligned}
$$

For this ventilation system, the standard ventilation scheme described above was used. In that scheme there is I prefilter, a first stage HEPA, and a second stage HEPA. All filters are assumed to have waste accumulations so that the contact dose rate is equivalent to 2 $\mathrm{mSv} / \mathrm{hr}$. In order to account for the loading on the ventilation ducting, another volume equal to a prefilter is assumed to be available for release. The the total volune in one bank of the ventilation system is.

$$
\begin{aligned}
M_{\text {bark }} & =:\left(M_{\text {HEPA }}\right)+2\left(M_{\text {pIefiIter }}\right) \\
& =:(0.0872)+2(0.0659) \\
& =(1.306 L
\end{aligned}
$$

The total amount of material released during a high pressure event, for this example, is found by multiplying the number of operating filter banks, the material $r \geq 1$ eased from one filter bank, and the release fraction of $1 / 100$ (D)E 1994).

$$
\begin{aligned}
M_{\text {total }} & =(\text { Number of Banks })\left(M_{\text {bank }}\right) \text { (Release Fraction) } \\
& =(2)(0.306)(0.01) \\
& =0.0061 \mathrm{~L}
\end{aligned}
$$




\section{REFERENCES}

Cowley, W. L., 1996, Develoument of Radiological Concentration and Unit Liter Doses for Tank liaste Remediation System Final Safety Analysis Report Radio'ogical Consequence Calculations, WHC-SD-WMSARR-037, Rev. 0, Wes:inghouse Hanford Company, Richland, Washington.

DOE, 1994, DOE Handbook Air,orne Release Fractions/Rates and Respirab7e Fractions fro Nonreacior Nuclear Facilities, DOE-HDBK-3010-94, U.S. Department of Entrgy, Washington, D.C.

Savino, A. V., 1996, MICROSilIELD Dose Rate Calculations for HEPA Filters and Prefilters, WHC-S[I-WM-CN-033, Rev. 0, Westinghouse Hanford Company, Richland, Wa:hington.

Van Keuren, J. C., and A. V Savino, 1996, Tank Waste Compositions and Atmospheric Dispersior Coefficients for use in Safety Analysis Consequence Assessmen1s, WHC-SD-WM-SARR-016, Rev. 2, West inghouse Hanford Company, Richland, Washington.

Van Vleet, R. J., 1996, Flanmable Gas Deflagration Consequence Calculations for the Tank Waste Remediation System Basis for Interim Operation, WHC-SD-WM-CN-055, Rev. 0, Westinghouse Hanford Company, Richland, Washington. 


\begin{tabular}{|c|c|c|c|c|c|c|c|c|c|c|c|c|c|}
\hline \multicolumn{5}{|c|}{ WHC-SD-WM-SARR-037 } & \multirow{2}{*}{\multicolumn{3}{|c|}{$\begin{array}{c}\text { SX, C-106 } \\
\text { SST Solids on a 3X3 Array of } \\
24 \times 24 \times 12 \text { Filters }\end{array}$}} & \multicolumn{6}{|c|}{ SSTs with Passive Breather Filters } \\
\hline & \multirow{2}{*}{ SST Solids } & \multirow{2}{*}{$\begin{array}{c}\text { SST Liquids } \\
\text { (Bq/L) }\end{array}$} & \multirow{2}{*}{$\frac{\text { DST Liquids }}{(\mathrm{Bq} / \mathrm{L})}$} & \multirow{2}{*}{ AWF Liquids } & & & & \multicolumn{3}{|c|}{ SST Solids on a $24 \times 24 \times 12$ Filter } & \multicolumn{3}{|c|}{ SST Solids on a $12 \times 12 \times 12$ Filter } \\
\hline & & & & & (Ci) & $(\mathrm{Bq})$ & (L) & (Ci) & $(\mathrm{Bq})$ & (L) & $(\mathrm{Ci})$ & $(\mathrm{Bq})$ & (L) \\
\hline Co60 & $4.2 E+08$ & $9.5 E+06$ & $7.0 \mathrm{E}+06$ & 7.7E+05 & & & & & & & & & \\
\hline Sr90 & $1.6 \mathrm{E}+12$ & 1.1E+10 & $4 . \overline{6} \bar{E}+09$ & $5.6 E+09$ & 0.4840 & $1.8 \mathrm{E}+10$ & 0.011 & 0.4840 & $1.8 \mathrm{E}+10$ & 0.011 & $0 . \overline{4840}$ & $1.8 \mathrm{E}+10$ & 0.011 \\
\hline Y 90 & $1.6 \mathrm{E}+12$ & $1.1 E+10$ & $4.6 \mathrm{E}+09$ & $5.6 E+09$ & 0.4840 & $1.8 \mathrm{E}+10$ & 0.011 & 0.4840 & $1.8 \mathrm{E}+10$ & 0.011 & 0.4840 & $1.8 \mathrm{E}+10$ & 0.011 \\
\hline Cs 137 & 1.0E+11 & $2.2 E+10$ & $5.9 E+10$ & $8.8 E+10$ & 0.0303 & $1.1 E+09$ & 0.011 & 0.0303 & 1.1E+09 & 0.011 & 0.0303 & $1.1 \mathrm{E}+09$ & 0.011 \\
\hline Eu154 & $5.8 \mathrm{E}+09$ & $2.4 E+09$ & $4.2 \mathrm{E}+07$ & $0.0 \mathrm{E}+00$ & 0.0017 & $6.3 E+07$ & 0.011 & 0.0017 & $6 . \overline{\mathrm{E}}+07$ & 0.011 & 0.0017 & $6.3 \mathrm{E}+07$ & $0 . \overline{011}$ \\
\hline Np237 & $3.0 \mathrm{E}+07$ & $0.0 \mathrm{E}+00$ & $2.3 E+05$ & $9 . \overline{2 E}+04$ & & & & & & & & & \\
\hline Pu238 & $1.9 \mathrm{E}+08$ & $9.2 E+04$ & $1.8 \mathrm{E}+06$ & $2.8 E+03$ & & & & & & & & & \\
\hline Pu239 & $4.4 \mathrm{E}+08$ & $3.6 \mathrm{E}+07$ & $7.7 \mathrm{E}+06$ & $1.2 E+06$ & & & & & & & & & \\
\hline Pu241 & $3.2 \mathrm{E}+09$ & $2.6 \mathrm{E}+08$ & $1.8 \mathrm{E}+07$ & $3 . \overline{4} \bar{E}+05$ & & & & & & & & & \\
\hline Am241 & $2.3 E+08$ & $4.2 \mathrm{E}+07$ & $3.4 E+07$ & 1.1E+06 & & & & & & & & & \\
\hline \multirow[t]{3}{*}{$\mathrm{Cm} 244$} & $2.3 E+06$ & $4.2 \mathrm{E}+05$ & $1.2 \mathrm{E}+05$ & 1.1E+04 & & & & & & & & & \\
\hline & & & & TOTAL & 1.00 & $3.7 E+10$ & 0.011 & 1.00 & $3.7 \mathrm{E}+10$ & 0.011 & 1.00 & $3.7 E+10$ & 0.011 \\
\hline \multirow{2}{*}{\multicolumn{5}{|c|}{ 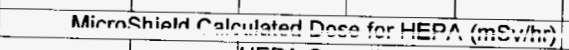 }} & & & & & & & & & \\
\hline & & & & & & & 0.257 & & & $i . \overline{7}$ & & & 4.13 \\
\hline & \multicolumn{4}{|c|}{ HEPA Operating Limit (mSv/hr) } & & & 2 & & & 2 & & & 2 \\
\hline & & & & OLCD & & & 7.782 & & & 1.129944 & & & 0.421053 \\
\hline & & \multicolumn{3}{|c|}{ HEPA Loading to give OL (L) } & & & 0.087245 & & & 0.012668 & & & 0.00472 \\
\hline & & & $1 \% \operatorname{Re}$ & elease (L) & & & $0 . \overline{000872}$ & & & 0.000127 & & & $4.72 E-05$ \\
\hline & & & & & & & & & & & & & \\
\hline \multicolumn{5}{|c|}{ Microshield Calculated Dose for Prefilter (mSv/hr) } & & & 0.34 & & & No Prefilter & & & No Prefinter \\
\hline & \multicolumn{4}{|c|}{ Prefilter Operating Limit (mSv/hr) } & & & 2. & & & & & & \\
\hline & & & & OLCD & & & 5.882353 & & & & & & \\
\hline & & \multicolumn{3}{|c|}{ Prefilter Loading to give $\mathrm{OL}$ (L) } & & & 0.065947 & & & & & & \\
\hline & & & \multicolumn{2}{|c|}{ 1\% Release $(L)$} & & & 0.000659 & & & & & & \\
\hline & & & & & & & & & & & & & \\
\hline \multicolumn{5}{|c|}{ Volume Released from One Filter Bank (L) } & D & D & 3.06E-03 & & $\mathbf{P}$ & $1.27 E-04$ & & $\mathbf{P}$ & $4 . \overline{72 E}-05$ \\
\hline \multicolumn{5}{|c|}{ Number of Parallel Banks Operating at the Same Time } & & & 2 & & & $1+$ & & & \\
\hline & & \multicolumn{3}{|c|}{ TOTAL RELEASED (L) } & & & $8.13 \mathrm{E}-03$ & & & $1.27 \mathrm{E}-04$ & & & $4 . \overline{72 E}-05$ \\
\hline & & & & & & & & & & & & & \\
\hline & $D=T$ & \multirow{2}{*}{\multicolumn{8}{|c|}{$\begin{array}{l}\text { Two HEPAs, a Prefither, and another volume equal to the prefitter for stuft coming out of the ventilation ducting } \\
2^{\prime} \text { HEPA Volume }+2^{*} \text { Prefitter Volume }\end{array}$}} & & & & \\
\hline & $=2$ & & $e+2^{*}$ Prefitter & r Volume & & & & & & & & & \\
\hline & $P=P$ & Passive breather & er HEPA, no pre & orefilter, no sec & nd HEPA, an & nd no apprecia & able ventilation & ducting & & & & & \\
\hline & $=1$ & 1"HEPA Volume & & & & & & & & & & & \\
\hline & $A=T$ & Two (2) HEPAs, & s, no prefilter bu & but there are tw & (2) de-entrai & iners and mate & terial in the ven & tilation ducting & $g(1)$ & & & & \\
\hline . & $=5$ & 5*HEPA Volume & & & & & & & & & & & \\
\hline & $C=T$ & Two HEPAs, ap & prefilter, a low & $\mathrm{V}$ efficiency filte & treated as a & prefilter), and & $\mathrm{d}$ another volum & ie equa & filte & rial is & & & \\
\hline & $=2$ & $2^{*}$ HEPA Volume & e $+3^{*}$ Prefilter & Volume & & & & & & & & & \\
\hline
\end{tabular}

Rick J. Van Vleet, Ph.D. 


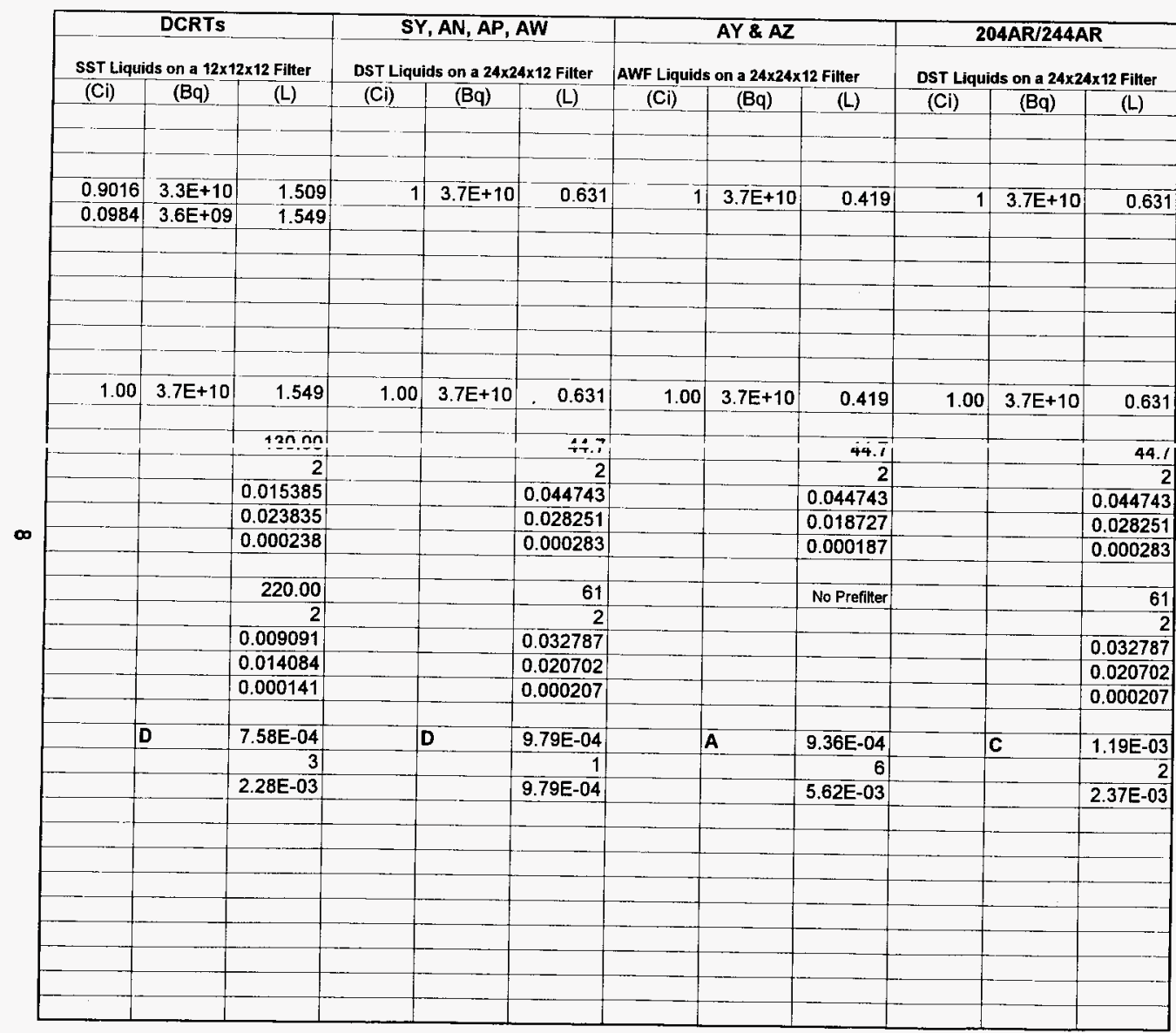




\section{CHECKLIST FOR PEER REVIEW}

Document Reviewed: WHC-SO-WM-CN-0j4, Rev. 0, Waste Tank Ventilation System Waste Material Accumllations

Scope of Review: Entire documen:.

Yes No NA

[ ] [ ] [X] * Previous reviews complete and cover analysis, up to scope of this review, with no gajis.

[X] [ ] [ ] Problem completely defined.

[X] [ ] [ ] Accident scenarios developed in a clear and logical manner.

[x] [ ] [ ]

[X] [ ] [ [ ]

Necessary assumptions explicitly stated and supported.

Computer codes and data files documented.

Data used in calcu ations explicitly stated in document.

Data checked for consistency with original source information as

$[X][][]$ Data checked

[ ] [ ] [ $]$ Mathematical derivitions checked including dimensional consistency of results.

[X] [ ] [ ] Models appropriate and used within range of validity or use outside range of established validity justified.

[X] [ ] [ ] Hand calculations checked for errors. Spreadsheet results should be treated exactiy the same as hand calculations.

[ ] [ ] [X] Software input correct and consistent with document reviewed.

Software output corsistent with input and with results reported in document reviewed.

[ ] [ ] [X] Limits/criteria/guidelines applied to analysis results are appropriate and referenced. Limits/criteria/guidelines checked against references.

[ ] [ ] [X] Safety margins consistent with good engineering practices.

[X] [ ] [ ] Conclusions consistent with analytical results and applicable limits.

[X] [ ] [ ] Results and conclusions address all points required in the problem statement.

[ ] [ ] [X] Format consistent with appropriate NRC Regulatory Guide or other standards

[ ] $[X]$ * Review calculations, comments, and/or notes are attached.

[X] [ ] [ ] Document approved.

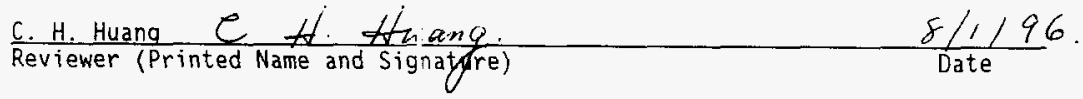

* Any calculations, comments, or notes generated as part of this review should be signed, dated and attached to this zhecklist. Such material should be labeled and recorded in such a manner as to be intelligible to a technically qualified third party. 


\begin{tabular}{|c|c|c|c|c|c|}
\hline \multicolumn{6}{|c|}{ DISTRIBUTION SHEET } \\
\hline \multirow{2}{*}{$\begin{array}{l}\text { To } \\
\text { Distribution }\end{array}$} & \multirow{2}{*}{\multicolumn{3}{|c|}{$\begin{array}{l}\text { From } \\
\text { R. J. Van Vleet }\end{array}$}} & \multicolumn{2}{|l|}{ Page 1 of 1} \\
\hline & & & & \multicolumn{2}{|c|}{ Date August 2, 1996} \\
\hline \multicolumn{4}{|l|}{ Project Title/Work Order } & \multicolumn{2}{|c|}{ EDT No. $\quad 614540$} \\
\hline \multicolumn{4}{|c|}{$\begin{array}{l}\text { TWRS BIO/WHC-SD-WM-CN-054, Rev. 0, Waste Tank Ventilation System } \\
\text { Waste Material Accumulations }\end{array}$} & \multicolumn{2}{|l|}{ ECN No. } \\
\hline \multicolumn{2}{|l|}{ Name } & $\begin{array}{c}\text { Text } \\
\text { With All } \\
\text { Attach. }\end{array}$ & Text Only & $\begin{array}{l}\text { Attach./ } \\
\text { Appendix } \\
\text { Only }\end{array}$ & $\begin{array}{c}\text { EDT/ECN } \\
\text { Only }\end{array}$ \\
\hline $\begin{array}{l}\text { C. M. Bellis } \\
\text { W. L. Cowley } \\
\text { R. L. Guthrie } \\
\text { C. H. Huang } \\
\text { G. D. Johnson } \\
\text { D. S. Leach } \\
\text { A. L. Ramble } \\
\text { G. W. Ryan } \\
\text { S. H. Rifaey } \\
\text { G. R. Sawtelle } \\
\text { R. L. Schlosser } \\
\text { R. J. Van Vleet }\end{array}$ & $\begin{array}{l}\text { A2-26 } \\
A 3-37 \\
A 3-37 \\
A 3-34 \\
S 7-14 \\
A 3-34 \\
A 3-38 \\
A 3-37 \\
R 1-56 \\
A 3-37 \\
R 1-56 \\
A 3-34\end{array}$ & $\begin{array}{l}x \\
x \\
x \\
x \\
x \\
x \\
x \\
x \\
X \\
X \\
X \\
X\end{array}$ & & & \\
\hline Central Files & A3-88 & $X(2)$ & & & \\
\hline
\end{tabular}

